\title{
Monetary Stability
}

\section{Competing Policy Objectives and Trade-offs}

The present chapter revisits the concept of monetary stability at the different levels of governance (domestic, regional and international). In doing so it argues that monetary stability, domestic and regional, is a clear policy objective entrusted by law or treaty to their corresponding monetary authorities on the premise of monetary sovereignty of states. This chapter thus explores the modern notion of monetary sovereignty and its main attributes for the issuance and regulation of money in a given jurisdiction. Based on these attributes of monetary sovereignty the states decide what is to be considered monetary stability within its territorial borders and how it is to be achieved and protected.

Notwithstanding the indisputable fact that monetary stability is a sovereignty issue, it also has an international dimension. This global dimension refers to the stability of the international monetary system (IMS) as a whole. Accordingly, this chapter considers the stability of the international monetary order with special emphasis on the roles of public international law and the central international monetary institution, International Monetary Fund (IMF or Fund). This chapter continues by pointing out that the different dimensions of monetary stability are not static and influence each other. Domestic and regional monetary systems are relevant parts of the international system and they have a direct influence on its stability or instability. Hence, this chapter argues that the main channel of influence is the collection of international spillovers of monetary policy. That is, in a world of highly interconnected financial and monetary systems, locally- and regionally-oriented policies have effects beyond their intended borders.

\section{Monetary Sovereignty Today}

International law recognises a state's sovereignty over its internal affairs within its territorial boundaries. Hence, sovereignty is usually defined as the supreme authority of a state within its own territory, only limited by the accepted rules of international public law. This means that 'a state that is not subject, within its territorial jurisdiction, to the governmental (executive, legislative, or judicial) jurisdiction of a foreign state or to foreign law other than public international 
law'. Jackson remarks that this aspect of sovereignty - i.e. the supreme authority in a given territory - derives from the traditional 'westphalian' concept of sovereignty and it relates to the notion of 'equality of states' and the correlative 'duty of non-intervention' by any foreign or international powers (unless consented to by the respective state). ${ }^{2} \mathrm{He}$ argues in consequence that there is a 'logical connection between the sovereignty concepts and the very foundation and sources of international law', implying that 'no international law norm is valid unless the state has somehow "consented" to it.' ${ }^{3}$

The power to issue and regulate currency is one of the undeniable sovereign attributes of a state. ${ }^{4}$ Notwithstanding that, the international community has not explicitly defined or recognised the concept of monetary sovereignty in any instrument of international law. In 1929 a judgment of the former permanent court of international justice acknowledged the principle of monetary sovereignty for the first time in modern international law (the Serbian Loans Case) by stating that it is indeed a generally accepted principle that a state is entitled to regulate its own currency. ${ }^{5}$ Consequently, states are obliged to recognize the attributes of monetary sovereignty of other states and also to accept such consequences of the exercise of monetary sovereignty.

According to Proctor the concept of monetary sovereignty presents both internal and external attributes. "Internal" sovereignty includes the rights to define the monetary system, to devalue the currency, and to operate a

1 See Rosa M Lastra, International Financial and Monetary Law (2nd edn, oup 2015) 5-6. For recent legal studies on the concept of sovereignty see John H Jackson 'Sovereignty Modern: A New Approach to an Outdated Concept' (2003) 97 AJIL 782; Anne-Marie Slaughter, A New World Order (Princeton: Princeton University Press 2004); Dan Sarooshi, 'The Essentially Contested Nature of the Concept of Sovereignty: Implications for the Exercise by International Organizations of Delegated Powers of Government' (2004) 25 Mich J Intl L 1107; Wenhua Shan, Penelope Simons and Dalvinder Singh (eds), Redefining Sovereignty in International Economic Law - Studies in International Trade Law (No.7) (Hart Publishing 2008).

2 The 'Treaty of Westphalia' is a peace treaty signed in 1648 among the Holy Roman Emperor and the King of France and their allies. The treaty does not contain an expressed notion of sovereignty but the interpretation of this treaty with the passing of the time contributed to the development of the concept of 'westphalian sovereignty' as we know today. See Jackson (n 1$) 786-787$.

3 Jackson (n 1$) 782$.

4 For an extended analysis of the notion of monetary sovereignty and its evolution please see, inter alia, François Gianviti, 'Current Legal Aspects of Monetary Sovereignty' in IMF (ed), Current Developments in Monetary and Financial Law, vol 4 (2005) 3-16; Lastra, International Financial and Monetary Law (n 1) 3-27; Claus D Zimmermann, A Contemporary Concept of Monetary Sovereignty (OUP 2013), ch 1.

5 Serbian and Brazilian Loan Cases, Judgment of 12 July 1929, Publications of the Court, Series A nos. 20-1, 44 and 122. 
monetary policy; "external" sovereignty includes the right to impose a system of exchange control'. ${ }^{6}$ Accordingly, he argues that while the exercise of the 'internal aspects' of monetary sovereignty cannot be challenged by other states and must be accepted and respected, the exercise and the scope of the 'external aspects' of monetary sovereignty may be questioned under the rules of public international law because of the extraterritorial impact that can affect other states. ${ }^{7}$ Notwithstanding that, a proper exercise of the attributes of monetary sovereignty of the states cannot be disputed before any national or international tribunal. ${ }^{8}$

States exercise monetary sovereignty in the issuance and regulation of money according to the law of the currency (lex monetae), which defines what money is and the nominal value that money has in a particular jurisdiction. Economic theory provides a useful definition of money based on its core four functions. These are: money as a commonly accepted medium of exchange, money as a means of payment, money as a unit of account, and money as a store of value. The importance of each of the functions have varied over time and the medium of exchange function is regarded nowadays as the key function of money. In consequence, the law must reflect that monetary debts can be paid by that medium of exchange. ${ }^{9}$ As remarked by Proctor, the lex monetae theory was developed by Mann on the premise of the universally accepted 'principle of nominalism'10 which 'applies to contractual arrangements and involves an obligation to pay the nominal amount of the debt in the currency

6 Charles Proctor, Mann on the Legal Aspect of Money (7th edn, OuP 2012) 526-528.

7 On this point Proctor cited what the Court held in the Case of Certain Norwegian Loans, 'the question of conformity of national legislation with international law is a matter of international law'. See Case of Certain Norwegian Loans (Francev Norway) [1957] ICJ Rep 9. Proctor (n 6).

9 For an extended legal study on the concept of 'money' see Proctor (n 6), ch 1. For the economic definition of money see the definition provided in Steven N Durlauf and Lawrence E Blume (eds), The New Palgrave Dictionary of Economics (2nd edn Palgrave Macmillan, 2008) <https://link.springer.com/referenceworkentry/10.1057/978-1-349-95121-5_2742-1> accessed 21 October 2021.

10 The 'principle of nominalism' is usually defined as: A debt expressed in the currency of another country involves an obligation to pay the nominal amount of the debt in whatever is the legal tender at the time of payment according to the law of the country in whose currency the debt is expressed (lex monetae), irrespective of any fluctuations which may have occurred in the value of that currency in terms of sterling or any other currency, of gold, or of any commodities between the time when the debt was incurred at the time of payment.

Albert Venn Dicey, John H.C. Morris, Lawrence Collins (eds), Dicey, Morris and Collins on the Conflict of Laws (15th edn, Sweet \& Maxwell 2012), rule 259. 
in which it was expressed." ${ }^{11}$ Hence money, as a creation of the law, is territorial and must be studied within a legal system.

The 'state theory of money', adopted in most modern constitutions, claims that money is what the law of the states dictate it to be and as a result falls within the jurisdiction of the issuing state. ${ }^{12}$ The 'state theory of money' was mainly developed by Mann who considered that:

in law, the quality of money is to be attributed to all chattels that are:

(a) issued under the authority of the law in force within the State of issue;

(b) under the terms of that law, denominated by reference to a unit of account; and

(c) under the terms of that law, to serve as the universal means of exchange in the State of issue.

Consequently, the 'state theory of money' can be considered as part of the law of the state. ${ }^{13}$ The scope of this traditional theory was the subject of debate by legal literature and two new theories emerged - firstly the 'societary theory of money' and more recently the 'institutional theory of money'.

The 'societary theory of money' claims 'that it is the usage of commercial life or the confidence of the people which has the power to create or recognize "money". ${ }^{14}$ Hence, according to this theory it is the attitude of the society and not the sovereign attribute of the state that recognizes what money is. The

11 Charles Proctor, 'Indexation and Value Clauses' in Mario Giovanoli and Diego Devos (eds), International Monetary and Financial Law, The Global Crisis (oup 2010) 576; Proctor (n 6), ch 9 .

12 For example, among others, the constitution of the United States of America states that 'The Congress shall have the power ... 5 . To coin money, regulate the value thereof, and of foreign coin, and fix the standard of weights and measures'. (US Const Art 1, §8). The Federal Constitution of the Swiss Confederation establishes that 'The Confederation is responsible for money and currency; the Confederation has the exclusive right to issue coins and banknotes. (Federal Constitution of the Swiss Confederation of 18 April 1999 Art 99, para 1). The Constitution of the Argentine Nation declares that 'Corresponds to the Congress ... 6. Establish and regulate a federal bank with the power to issue currency ... 11. To seal currency, fix its value and that of foreign companies; and adopt a uniform system of weights and measures for the whole nation'. (Constitución Argentina Art 75).

13 Proctor (n 6) 15, citing FA Mann, The Legal Aspects of Money (5th edn oup, 1991) 8.

14 Proctor (n 6) 24. The 'societary theory of money' was established by legal literature among the nineteenth and twentieth centuries by Friedrich Carl von Savigny and Arthur Nussbaum. See Zimmermann (n 4) 13. 
'institutional theory of money' developed recently by Sainz de Vicuña, former general counsel of the European Central Bank (ЕСB), considers that money 'is no longer a chattel, but a transferrable credit within an overall institutional legal framework. ${ }^{15} \mathrm{He}$ advocates that the 'state theory of money' is outdated and that money is more than physical banknotes and coins but also 'scriptural money' (that is, demand deposits in credit institutions). This 'scriptural money' is widely accepted by society because it is based on a strong institutional framework - an independent central bank in control of the amount of money, both physical and scriptural, in a national economy. ${ }^{16}$

Notwithstanding the emergence of the new theories, a broad interpretation of the 'state theory of money' is still dominant. Lastra argues that:

Though the societary theory of money provides an important complementary approach to the legal study of money, as long as we have a system in which the state keeps an important role in money creation (with regard to the issue of currency), control of the money supply through monetary policy (a function entrusted to a central bank, usually with independence from political instruction, yet a state function), and a certain degree of control over the banking and financial system through regulation and supervision and oversight of payment systems, the state theory of money - broadly understood as the public legal framework in which the economic institutions of money and central banking operate remains valid in my opinion. ${ }^{17}$

Under the precepts of international law states are obliged to recognise the sovereign powers of other states in monetary affairs. However, this monopoly power of states in the monetary field is no longer absolute and has been subject to some limitations. As explained by Lastra, the limitations to monetary sovereignty are both consensual and de facto. 'Consensual limitations represent a voluntary surrender of monetary sovereignty. De facto limitations are the result of globalisation, the information revolution and of economic and financial developments during the last three decades of the twentieth century'.18 Zimmermann argues that legal constraints to the monetary sovereignty

15 Antonio Sainz de Vicuña, 'An Institutional Theory of Money' in Giovanoli and Devos (eds), International Monetary and Financial Law (n 11) 517.

16 ibid.

17 Lastra (n 1$) 18$.

18 Rosa M Lastra, 'The Role of Central Banks in Monetary Affairs: A Comparative Perspective' in Thomas Cottier and others (eds), The Rule of Law in Monetary Affairs (CUP 2014) 98. 
of states play a minor role in comparison to the de facto economic constraints that emerge from economic globalization and integration of financial markets. ${ }^{19}$ The dominant role of global financial markets impacts de facto on some formal state competences in the realm of monetary and financial affairs. Also, the de facto use of a foreign currency, such as the USD or the euro, as a store of value, unit of account and/or medium of exchange by the residents of a certain country, in parallel or instead of the local currency represents a limitation to monetary sovereignty. ${ }^{20}$

The Articles of Agreement of the ImF (Articles of Agreement) - specifically Article IV (code of conduct) and VIII (general obligations) - contain the most prominent consensual limitation to the attributes of monetary sovereignty of the state members at the international level. ${ }^{21}$ The creation of the Economic and Monetary Union (EMU) in 1999 in Europe is the most notable example of the consensual limitation of monetary sovereignty at the regional level. The member states of the EMU transfer to the regional level (ЕСB) the attribute of currency creation (euro). With respect to this transfer of monetary sovereign powers in Europe from the national level to the regional level, Lastra considers that 'the surrender of monetary sovereignty does not imply the erosion of national sovereignty in other respects. It is a limited surrender, a non-exclusive transfer of sovereign powers. The members of the Euro zone retain their national sovereignty in those domains where no other consensual limitation has been agreed'. ${ }^{22}$

Moreover, there were other attempts to regional monetary integration in Europe before the formation of the EMU. Sweden and Denmark fixed their currencies against each other by reference to a gold par value in 1873 and Norway joined in 1875. This Scandinavian union did not create either a common currency or a central monetary authority. The start of the first

19 Zimmermann (n 4) 17. Robert Howse provides an interesting analysis of the relation between globalization and sovereignty by considering that: In understanding the significance of globalisation ... for sovereignty we must always bear in mind the fundamentally dual or ambiguous nature of the concept - that it remains both a statement of a normative ideal (connected to self-determination, cultural and national autonomy, democracy, and related concepts) and a judgment about the actual capacity of states and/or their governments to affect or determine outcomes.

See Robert Howse, 'Sovereignty, Lost and Found' in Wenhua Shan, Penelope Simons and Dalvinder Singh (eds), Redefining Sovereignty in International Economic Law (Hart Publishing 2008) 61-75.

$20 \quad$ Zimmermann (n 4) 188.

21 For a more extensive study of these IMF Articles see chapters 5 and 6 of this book.

22 Lastra (n 1$) 22$. 
world war put an end to this monetary union. France, Belgium, Italy and Switzerland established the Latin Monetary Union in 1856 with Greece joining at a later date. In this union, the currency of each member state was accepted as legal tender through the union, and the central banks of the members accepted the coins of the other central banks at par without limitations. This monetary union was also dissolved with the outbreak of the first world war. Again, this union did not involve a common currency or supranational monetary institution. Belgium and Luxembourg created a monetary union in 1922 that was only ended with the advent of the EMU in 1999. In this long-lasting union the Belgian franc was legal tender in both countries but only the Belgian national central bank issued the currency. Beyond the monetary union examples in Europe, there are monetary unions in Africa and the Caribbean. ${ }^{23}$

In addition to the consensual limitations of monetary sovereignty, Proctor remarks that the conduct of monetary affairs is not only limited but also assisted by the rules of public international law through specific treaty provisions and also by rules of customary international law. ${ }^{24}$ Article 38 of the Statute of the International Court of Justice states that the primary sources of international law are international treaties, customary international law and general principles of law accepted by all nations. ${ }^{25}$ For the purposes of this study the primary sources of international law in international monetary affairs are the Articles of Agreement, the applicable customary international law and general principles of law.

Notwithstanding the consensual and de facto limitations to monetary sovereignty, states remain as key actors in the exercise of their own attributes of monetary sovereignty. This situation was emphasised by the remarkable return to national frontiers (or de-globalization) in financial and monetary affairs as evidenced during the 2007-2009 global financial crisis (G FC) and its aftermath. However, the sovereign power of states is no longer absolute. As remarked by Lastra, 'Centripetal and centrifugal forces have diffused the power of the nation state, and today a variety of actors, including international organizations, multinational corporations, regions, local communities, and the civil society also exercise power. ${ }^{26}$ It is in this context that Zimmermann argues that a contemporary concept of monetary sovereignty can be understood both in a direct manner by focusing only

\footnotetext{
23 Proctor (n 6) 671.

24 Proctor (n 6) 587.

25 Statute of the International Court of Justice, art 38.

26 Lastra (n 1) 21.
} 
on the supreme authority of states and also in an indirect manner as form of 'cooperative sovereignty' that can be exercised at the different layers of governance. This is done by considering 'the various sovereign powers that originally all derive from the same source, namely the capacity of independent statehood'.27

Another timely example of the change of powers in monetary affairs is the emergence of local or regional currencies and of virtual or digital currencies. The local or regional currencies, also known as community currencies or parallel currencies, 'are currencies that are not legal tender and are intended to be used in parallel to the respective national currency and which trade only in a rather limited geographical area and usually not across borders.' ${ }^{28}$ The most prominent examples today are the Brixton Pound and the Stroud Pound in the United Kingdom and the Chiemgauer in Germany. The virtual or digital currencies are 'digital representations of value, issued by private developers and denominated in their own unit of account'.29 This concept is wide and encompasses internet and mobile coupons as well as cryptocurrencies like the widely known Bitcoin. ${ }^{30}$ For an expanded analysis on virtual currencies see chapter 5 section 1.1.3 on this book.

27 Zimmermann (n 4) 18. He argues in favor of contemporary monetary sovereignty as cooperative sovereignty by stating that 'in light of the increasing integration of financial markets and the interdependence of "national" economies, the effective promotion of global monetary and financial stability requires cooperation among those exercising sovereign powers in the realm of money and finance'. Also, Zimmermann argues that: The concept of sovereignty has indeed always been deeply rooted in safeguarding peace, order and prosperity, in accordance with ultimate goals of international law. And in light of contemporary challenges, such as global climate change and the increasing integration of financial markets, these goals can best or exclusively be achieved by means of international cooperation. Cooperative, or shared, sovereignty is the therefore indeed the only realistic option at hand.

Claus D Zimmermann, closing statement in Thomas Cottier (ed) The Prospects of Common Concern of Humankind in International Law (CUP 2O21).

28 Zimmermann (n 4) 14.

29 Dong He and others, 'Virtual Currencies and Beyond: Initial Considerations' (2016) IMF Staff Discussion Note 16/o3, 7 <https://imf.org/external/pubs/ft/sdn/2016/sdn16o3.pdf> accessed 21 October 2021. On virtual currencies also see European Central Bank, 'Virtual Currency Schemes' (2012) <https://www.ecb.europa.eu/pub/pdf/other/virtualcurrency schemes201210en.pdf> accessed 21 October 2021; Zimmermann (n 4) 14-15.

30 For a critical legal study on Bitcoin see Jonathan Turpin, 'Bitcoin: The Economic Case for a Global, Virtual Currency Operating in an Unexplored Legal Framework' (2014) 21 Indiana Journal of Global Legal Studies 335 . 
The concept of monetary stability is intrinsically linked with the sovereign power of states in the realm of money. As remarked by Lupo-Passini, 'The power to devise and implement economic policies or maintain domestic stability is legally structured as a sovereign prerogative.' ${ }^{31}$ It is under the exercise of their attributes of monetary sovereignty that the states define what is to be considered monetary stability at the domestic level. According to Lastra, "The "stability culture" is in itself a modern phenomenon, which has influenced legislative developments in recent decades. ${ }^{32}$

Monetary stability was included in central bank laws and statutes as the core objective of its monetary policy since the late twentieth century. In the aftermath of the GFC some central banks also consider financial stability as the primary or concomitant objective of their monetary policy together with monetary stability. This stability phenomenon is not only confined to the domestic sphere. It also has a regional and an international dimension. These dimensions are not static and influence each other through spillover effects or cross-border externalities generated by policies and decisions aimed to achieve a desired level of stability in the domestic sphere. It can be argued that the main reason for the existence of those spillovers is the very nature of interconnectedness of the global financial and monetary systems. A study prepared by the IMF highlights that:

The rapid financial globalization of the past three decades - reflected in the over six-fold increase in the external assets and liabilities of nations as a share of GDP ... - has been accompanied by an increase in financial interconnectedness. Countries have become more and more interlinked with each other, particularly since the mid-199o's, as the asset and liability management (ALM) strategies of their sovereigns, financial institutions, and corporations have become increasingly global in nature. ${ }^{33}$

31 Federico Lupo-Pasini, 'Financial Stability in International Law' (2017) 18(1) MJIL 52.

32 Lastra (n 1) $55^{-56}$.

33 IMF, 'Understanding Financial Interconnectedness' (2010) <http://imf.org/en/Publicati ons/Policy-Papers/Issues/2016/12/31/Understanding-Financial-Interconnectedness-PP4 503> accessed 21 October 2021. 


\subsection{Domestic Monetary Stability}

Monetary stability is both a fundamental economic goal and an essential monetary policy objective. Lastra provides a definition of monetary stability that considers both a positive and a negative perspective:

In positive terms, monetary stability refers to the maintenance of the internal value of money (i.e., price stability) as well as of the external value of the currency (e.g., the stability of the currency vis-à-vis other currencies, which is, in turn, influenced by the choice of exchange rate regime). In negative terms, monetary stability refers broadly to the absence of instability. ${ }^{34}$

Gianviti, a former general counsel of the IMF, offers a positive notion, 'Monetary stability means that the value of the currency should be preserved, but this could be understood in terms of preserving its external value (that is, exchange rate), or its internal value (that is, domestic prices), or both.' ${ }^{35}$ There is no universally accepted definition for monetary stability. Also, sometimes monetary stability is used as a synonym of price stability. However, as clarified in the previously mentioned definitions, price stability refers only to the internal aspect of monetary stability without considering the external dimension.

While 'internal monetary stability' refers to the stability of domestic prices and is generally measured by the consumer price index calculated by a public agency, ${ }^{36}$ 'external monetary stability' is understood as the stability of the value of a specific currency vis-à-vis other currencies and the law refers to it in very ambiguous terms. On this point Lastra considers that the law is ambiguous about the external dimension of domestic monetary stability because 'the issue of which is the best exchange rate arrangement for a given country (fixed, floating, or some version of managed float) remain a matter of great controversy'.37 The law follows the long standing debate on macro-economic

\footnotetext{
34 See Lastra (n 1$) 56$.

35 See François Gianviti, 'The Objectives of Central Banks', in Mario Giovanoli and Diego Devos (eds), International Monetary and Financial Law (n 11$) 465$.

36 The Oxford Dictionary of Finance and Banking states that the Consumer Price Index (CPI): 1. In the UK, ... a measure of price level introduced in 1997 to enable comparisons within the EU. ... 2. In the USA, the measure of price level calculated monthly by the Bureau of Labor Statistics. It is commonly known as the cost-of-living index and gives the cost of specific consumer items compared to the base year of 1967 .

Jonathan Law and John Smullen (eds), A Dictionary of Finance and Banking (4 rev ed, OUP 2008).

Lastra (n 1$) 6$ o.
} 
policy about stability or flexibility when it comes to monetary and exchange rate policies. ${ }^{38}$

Gianviti highlights that most central banking laws refer to monetary stability in its internal aspect as the main objective of monetary policy because 'a price stability objective may initially be compatible with an exchange rate objective, but in the medium or long term these two objectives are incompatible' ${ }^{39}$ For example, the ESCB's 'primary objective ... shall be to maintain price stability', 40 the Fed, to 'promote ... stable prices' ${ }^{41}$ and the Bank of England, 'to maintain price stability' 42

The price stability target pursued by the central banks, through monetary policy as the single tool, follows the so called 'Tinbergen Rule., ${ }^{43}$ This rule relies on the assumption that each policy objective correlates to a policy instrument. Multiple policy objectives should be achieved with multiple instruments otherwise some of the targets will be missed or under achieved. That said, the rule applied to monetary affairs is: one goal - monetary stability, one instrument monetary policy, performed by one institution - the central bank.

The Tinbergen Rule prevailed in central banking since the 199o's. However, it was challenged by the GFC because central banks now have to achieve several goals, in particular the rediscovered objective of financial stability, by resorting to a wider set of instruments. ${ }^{44}$ According to Zimmermann, financial stability

38 It was Milton Friedman who made a strong case for flexible exchange rates in a seminal contribution in 1953. Milton Friedman, 'The Case for Flexible Exchange Rates', published in Essays in Positive Economics (University of Chicago Press, 1953).

39 Gianviti (n 35) 473. To illustrate the issue of conflicting monetary policy objectives Zimmermann provides the following example, 'a central bank that increases the monetary base in order to prevent its currency from appreciating in line with economic fundamentals, thereby aiming to maintain an unrealistic currency peg, will in the long run fuel inflation, thus endangering domestic price stability'. Zimmermann (n 4$) 25$ (footnote omitted).

40 Treaty on the Functioning of the European Union [2008] oJ C115/47 Art 127 and Protocol (No 4) on the Statute of the European System of Central Banks and of the Есв [2010] оJ $\mathrm{C}_{326 / 230}$ Art 2.

4112 US Code 226 Federal Reserve Act, Section 2 A.

42 Bank of England Act 1998, Section 11.

43 Jan Tinbergen, On the Theory of Economic Policy (North Holland Pub Co 1952).

44 In US, the Dodd Frank Act 2010 reinforced the mandate of financial stability of the Federal Reserve System. In UK, the law governing the Bank of England was changed to include financial stability together with monetary stability as dual mandate. In the EU, despite monetary stability remaining as the primary objective in the Treaty, the mandate of the ЕСв has been expanded through secondary law during the GFC and a new 'banking union' is underway. For a detailed explanation of these regulatory changes and the rediscovered objective of financial stability see Lastra (n 1) 29-110; Rosa M Lastra and Charles A E Goodhart, 'Interaction Between Monetary Policy and Bank Regulation' (2015) 
is not a target of monetary policy but central banks have no choice and should achieve both objectives together. ${ }^{45}$ Financial stability refers to the stability of the financial system as a whole. Consequently, authorities have turned to macro-prudential instruments to deal with financial stability considerations. Macro-prudential tools are at the centre of monetary policy and micro-prudential instruments, thus adding a new layer of complexity to central bank operations, institutional design and responsibilities. ${ }^{46}$

\subsection{International Monetary Stability}

International or global monetary stability refers to the stability of the whole IMS. Domestic and regional monetary systems are relevant parts of this international dimension and they have a direct influence on its stability or instability. According to the Fund's view, ${ }^{47}$ the stability of the IMs refers to the stability of the overall system of exchange rates in accordance with the purpose of the Fund as stated in the Article I, (iii) of the Articles of Agreement, that is, "To promote exchange stability, to maintain orderly exchange arrangements among members, and to avoid competitive exchange depreciation'.

However, as stated in the previous chapter the stability of the IMS goes beyond stability of exchange rate agreements and also depends on the stability of the other key elements of the system. These are the international payments system, international capital movements, and monetary reserves and access to liquidity. The stability of the IMs relies on the smooth operation of each of these core elements or, in other words, the stability of the countries' balance of payments position.

The role of the IMF as the central international monetary institution has evolved since its conception, but its primary purpose to 'ensure the stability of the international monetary system - the system of exchange rates and international payments that enables countries (and their citizens) to transact

Monetary Dialogue Papers - European Parliament <www.europarl.europa.eu/committees/en/econ/monetary-dialogue.html?id=20150914CPUo5481 $>$ accessed 21 October 2021.

45 Claus D Zimmermann, 'Global Benchmark Interest Rates: conflicting objectives and increasing hybridisation' in Cottier and others (eds), The Rule of Law in Monetary Affairs (n 18).

46 As pointed by Lastra, 'The trend after the global financial crisis is to give the central bank responsibility for financial stability (macro-prudential supervision) and for micro-prudential supervision (directly as in the case of the ЕС Bank of England)'. See Lastra (n 1) 111-146.

47 IMF, 'Modernizing the Legal Framework for Surveillance - An Integrated Surveillance Decision' (2012) <http://imf.org/external/np/pp/eng/2012/ o71712.pdf> accessed 21 October 2021. 
with each other'48 remains unchanged. With the entry into force of the Second Amendment the Fund shifted the centre of its activities from a rule-based system monitoring the 'par value' regime to a surveillance-based function ${ }^{49}$ (that, coupled with the other key IMF functions, namely conditional financial assistance, provides the post Second Amendment raison d'etre of the IMF). ${ }^{50}$

According to new 'jargon' incorporated by the IMF in its 2007 Decision on Bilateral Surveillance over Member's Policies ${ }^{51}$ and the subsequent 2012 IMF Decision on Bilateral and Multilateral Surveillance $e^{52}$ the term that covers stability of the overall IMS is 'systemic stability'. These decisions also clarify that the Fund considers that 'systemic stability' is achieved by a combination of both 'balance of payment stability' and 'domestic stability' of each of its members. The concept of 'balance of payments stability' is defined as 'a balance of payments position that does not, and is not likely to, give rise to disruptive exchange rate movements' 53 and the concept of 'domestic stability' refers to the 'policies that are consistent with members' obligations under Article IV, Section 1 and, in particular, the specific obligations set forth in Article IV, Section 1, (i) through (iv). ${ }^{4}$

While recognizing the relevance of the new concepts introduced by the Fund's 'jargon', the concept of 'systemic stability' does not fully encapsulate the concept of 'international monetary stability' that this book aims to cover. The main reason for this is that the Fund's 'systemic stability' term only

48 IMF, The IMF at a Glance (2021) <http://imf.org/About/Factsheets/IMF-at-a-Glance?pdf= $1>$ accessed 21 October 2021. Article I of the Articles of Agreement enumerates the objectives of the IMF in a detailed manner.

49 According to Guitián this surveillance-based function of the IMF is discretionary and thus judgement is of the essence. However, he also remarks that the discretion is limited by the code of conduct enshrined in the Articles of Agreement. Manuel Guitián, 'The Unique Nature of the Responsibilities of the International Monetary Fund' (1992) Pamphlet Series No 46 <https://imf.org/external/pubs/ft/pam/pam46/pam46con.htm> accessed 21 October 2021.

$50 \quad$ IMF, The Fund's Role and Mandate - An Overview (2010) <http://www.imf.org/external/ np/pp/eng/2010/o12210a.pdf > accessed 21 October 2021; IMF, The Fund's Mandate - The Legal Framework (2010) <http://imf.org/external/np/pp/eng/2010/o22210.pdf> accessed 21 October 2021.

51 IMF, 'IMF Executive Board Adopts New Decision on Bilateral Surveillance over Members' Policies' (Public Information Notice, PIN 07/69, 15 June 2007) <https://imf.org/external/ $\mathrm{np} / \mathrm{sec} / \mathrm{pn} / 2007 /$ pno769.htm\#decision $>$ archived at <https://perma.cc/3C3A-MQ6P> accessed 21 October 2021.

$5^{2} \quad$ IMF, 'Modernizing the Legal Framework for Surveillance' (n 47).

53 ibid 16. This term was previously known as 'external stability' and it was changed for clarification purposes to 'balance of payment stability'. ibid 16. 
considers the cross-border or spillover effects of the domestic policies to the extent which they affect the exchange rate system of Article IV of the Articles of Agreement. This book deals with a broader notion of 'international monetary stability' that covers the cross-border or spillover effects of domestic policies when they have a negative or destabilizing impact on any of the elements of the IMS and is not limited to exchange rates. Consequently, the use of the term 'international monetary stability' through this book refers to the smooth functioning of the core elements of the IMS in an integrated global economy and in absence of cross-border negative spillovers generated by domestic monetary policies. ${ }^{55}$

There are also other international actors that play a fundamental role in the functioning of the IMS:

the World Trade Organization focuses on the regulation of international trade. The Bank for International Settlements (BIS), aims to foster international monetary and financial stability, acting as a forum for "cooperation among central banks and the financial community". The Financial Stability Board (FSB) focuses on promoting international financial stability. And the World Bank's overarching goal is poverty reduction through inclusive and sustainable globalization. ${ }^{56}$

Besides these actors and since the onset of the GFC, the Group of Twenty (G2O) assumed a fundamental role as an informal political forum for the coordination and promotion of reforms to the international financial and monetary system. ${ }^{57}$

55 Financial and fiscal policies are at the core of the economic policies of the state together with monetary policy. They interact among each other and in some scenarios, especially during crises times, the frontiers between those polices become blurred. Hence, while recognizing that it is impossible to exclude financial and fiscal policies entirely from a comprehensive study of monetary stability, the proposed definition for 'international monetary stability' in this book does not cover the financial or fiscal policies that can have a cross-border impact on the countries and it is limited to monetary related policies. Lupo-Pasini, on the contrary, in his very interesting study about financial stability in international law provides a definition of global stability 'as the absence of global systemic risk or negative cross-border spillovers in an integrated economic system' clarifying that, 'Global stability is ... the situation in which each state is not affected in its domestic stability by external spillovers from partner countries' monetary, financial, or fiscal policies'. Lupo-Pasini (n 31$) 53$.

56 IMF, 'Strengthening the International Monetary System: Taking Stock and Looking Ahead' (2011) < https://www.imf.org/external/np/pp/eng/2011/o32311.pdf> 21 October 2021.

Zimmermann (n 4) 192. 


\section{International Spillovers of Monetary Policy and Their Impact on Monetary Stability}

As argued before, international monetary stability depends on a delicate balance between the stability of domestic systems and the stability of the overall monetary system. Domestic monetary stability is an essential regulatory objective based on the monetary sovereign attributes of the states. As a consequence of globalisation and financial integration, the borders separating the different levels of governance have become blurred. Consequently, monetary policies and actions taken by one participant of the system (domestically or regionally) aimed at fulfilling domestic objectives within the scope of specific mandates may have a cross-border impact with spillover effects on other participants and also on the monetary system as a whole. ${ }^{58}$

As expressly recognized by the Fund in the preamble of the Integrated Surveillance Decision, 'there have been significant developments in the global economy that have highlighted the extent of trade and financial interconnections and integration and the potential benefits and risks of spillovers across national borders. 59 The term preferred by the Fund's terminology to refer to the cross-border effect of domestic and regional monetary policies is 'spillovers' and it is the term that I chose to use throughout my book because it better reflects these positive or negative cross-border effects of monetary policy and it distinguishes from the term 'externalities' used mostly by economists. ${ }^{60}$

Central banks and monetary authorities worldwide reacted to events of the GFC not only by using conventional monetary policy tools (like changes in the interest rate policies) but also unconventional monetary policy instruments. These unconventional tools comprise 'credit support, credit easing, interventions in foreign exchange and securities markets, provision of liquidity in foreign currency and quantitative easing (QE) $\cdot{ }^{\prime}{ }^{61}$ It can be

$5^{8}$ Palais-Royal Initiative, 'Reform of the International Monetary System: A Cooperative Approach for the Twenty First Century' (2011) < http://global-currencies.org/smi/gb/telec har/news/Rapport_Camdessus-integral.pdf > accessed 21 October 2021.

$59 \quad \operatorname{IMF}(\mathrm{n} 47) 4$.

6o Most central bank press releases and legal and economic literature refer to monetary policy 'spillovers'. The economic concept of 'externalities', firstly laid out by Alfred Marshall and later refined by Arthur Pigou, consider both 'the beneficial or negative effects on third parties arising out of the behaviour of agents that are not internalised by the agents. Third parties, therefore, either enjoy the beneficial effects of another party's behaviour without paying for them, or they suffer the costs of those behaviours without remedy'. See LupoPasini (n 31$) 59$.

61 Lastra $\left(\mathrm{n}_{1}\right)$ 41-42. For an extended analysis of the unconventional monetary policies taken since the GFC see Claudio Borio and P Disyatat, 'Unconventional Monetary Policies: An 
inferred that the main reasons for turning to unconventional tools were the expansion of the objectives of central banks (financial stability, growth, employment) and the lack of effectiveness of the existing instruments to tackle the problems that arose during such a crisis (e.g. in a world of zero lower bound, changes in the interest rate policy are no longer effective). ${ }^{62}$ These unconventional tools are meant to be exceptional and temporary: exceptional measures for exceptional times. These measures have also raised the debate about the interaction between monetary and fiscal policy and remain controversial. ${ }^{63}$

After a decade of experience with unconventional monetary policy tools (UMP T s) the Committee on the Global Financial System of the BIS published in October 2019 a report entitled 'Unconventional monetary policy tools: a crosscountry analysis' (the Report on UMPT s). ${ }^{64}$ The Report on UMPT s studied four sets of UMPT s: negative interest rate policies, new central bank lending operations, asset purchase programmes, and forward guidance. It offers a summary of central banks' common understanding of the efficacy of these instruments across countries and discusses how they were structured and coordinated from the onset of the GFC until the release of the report. According to the report, the use of UMPT s aims at:

broadly pursuing two main objectives: (i) addressing disruptions in the monetary policy transmission chain (DTC events); and (ii) providing additional monetary stimulus once the main conventional instrument (the policy rate) was constrained by the effective lower bound (ELB).

Appraisal' (2009) BIS Working Paper No 292 <www.bis.org/publ/work292.pdf> accessed 21 October 2021.

62 Proctor pointed out that 'The limitations on the ability of interest rates to influence economic activity have, however, become apparent as a result of the recent economic crisis'. Proctor (n 6), 95. Also see Zimmermann (n 4) 86-87.

63 In a recent note prepared by the IMF Legal Department the authors consider that the unconventional measures adopted by central banks to address crises 'could be considered to take place in the "twilight zone" between monetary policy and quasi-fiscal operations'. See IMF, 'Central Bank Exceptional Measures in the COVID-19 Crisis: Key Legal Design Issues' (2021) 6 <www.imf.org/en/Publications/SPROLLs/covid19-special-notes\#Legal> accessed 21 October 2021.

64 BIS, 'Unconventional monetary policy tools: a cross-country analysis' (October 2019) <www.bis.org/publ/cgfs63.htm> accessed 21 October 2021. Report prepared by a Working Group chaired by Simon M Potter (Federal Reserve Bank of New York) and Frank Smets (European Central Bank). 
The assessment of central banks is that UMPT s were effective in terms of both these objectives but that they also have their limits. ${ }^{65}$

The Report on UMPTs provides a brief overview of the types of UMPT s and the main examples are summarised as follows: 66

Negative interest rate policy (NIRP): Before the GFC there was a perception that interest rates should be positive. Thus, the adoption of negative interest rates was new and they were considered unconventional because they imply a cost for the owner of excess reserves while placing them with the central bank and their implementation required some modification of the policy framework. The first central bank to introduce negative rates was the Riksbank in July 20og. The European Central Bank (ЕСв), the Danmarks Nationalbank (DN), the Swiss National Bank (SNB) and the Bank of Japan (BoJ) also announced negative rates between 2014 and 2016. NIRPs were adopted in some cases to address currency appreciation pressures (e.g. in Switzerland) and in other cases to further ease monetary policy to ensure the anchoring of long-term inflation expectations (e.g. in the European Union).

Expanded lending operations (LOs): At the beginning of the GFC the liquidity in money markets was scarce and central banks responded by taking measures to facilitate the financial institutions' access to liquidity. Hence, the second group of UMPTs entailed expanded lending operations to financial intermediaries. The main reason behind this was that in many jurisdictions, lending is an integral part of the central bank's toolkit. Hence, while the new Los were not always new from a qualitative perspective, their scope, duration and size were unprecedented. The main objective was to provide ample liquidity to a broader group of financial institutions at the same time, under considerably looser conditions, for longer periods, and probably at a lower cost. Los helped stressed financial intermediaries to provide credit to the economy, overcoming blockages in policy transmission.

The Report on UMPTs mentions as examples of LOs the backstop facilities established by central banks to facilitate access to liquidity in the event financial intermediaries were unable to fund themselves in the market at sufficiently low rates. The Term Securities Lending Facility Options Programme was launched by the Federal Reserve (the Fed) in July 2008. The Bank of Canada $(\mathrm{BoC})$ created in 2008 the Term Loan Facility and the Term Purchase and Resale Agreement for Private Sector Instruments as backstop facilities.

65 ibid 1.

66 ibid 9. The summary on the four types of UMPTs and their corresponding examples are adapted from the Report on UMPTs. 
Asset purchase programmes (APPS): While open market purchase of domestic sovereign debt is a common feature in central banking, large-scale purchases of longer-term and private sector assets during the GFC were new and controversial. As discussed in chapter 5 of this book, purchasing private assets usually goes beyond the scope of central banks' mandates and such activities have given rise to several criticisms. The Report on UMPTs explains that:

The typical rationale for central banks' use of large-scale asset purchases was their impact on asset prices. Purchases of government and private sector debt reduce relevant interest rates and associated risk premia, and thus potentially bypass impaired links in the transmission chain, lowering borrowing costs for the real economy. Purchases that remove safe assets from investors' portfolios can, through a substitution effect, stimulate demand for riskier assets, relaxing financial conditions, with the expectation that this will stimulate aggregate spending. ${ }^{67}$

The Report on UMPTs mention that seven central banks reported the use of large-scale APP s: the Bank of Mexico, the Bank of England (BoE), the BoJ, ЕСв, the Fed, Riksbank and sNB between 2008-17. The APPs have different characteristics and pursue different objectives. These programmes aimed to address disruptions in the transmission of monetary policy or to provide additional monetary stimulus, or both. The QE programmes undertaken by the BoE, BoJ, $\mathrm{ECB}$, and the Fed are considered as APPS.

Forward guidance (FG): The fourth group of UMPTs is forward guidance. Forward guidance entails communication by central banks to the public about their intentions concerning future policy actions to influence policy expectations. While communication about the future setting of short-term policy rates is not new, the use of FG to inform of future UMPTs such as LOs and APPS was introduced during the GFC. According to the report, "The success of FG depends critically on the ability of central banks to effectively communicate their intentions and to support the credibility of their announcements. ${ }^{68}$ The Fed and the BoC introduced FG early on, in December 2008 and April 2009 respectively. The ЕСв and the BoE followed in July and August 2013 respectively. For Riksbank, methods for providing FG regarding the repo rate were unchanged from before the GFC, but new FG was added for asset purchases

67 ibid 12.

68 ibid 12. 
and foreign exchange interventions. Since 1999, the BoJ has used FG mostly on occasions that it eased policy.

The Report on UMPT s concludes that UMPT s have helped the central banks that used them to address and mitigate crisis circumstances. However, it also identifies some collateral effects, such as disincentives to private sector deleveraging and spillovers to other countries. The Report on UM PTs also debates whether and how these instruments could be useful in the future, since they are already part of the central bank's monetary policy toolbox. On this issue the Report on UMPTs pointed out that the use of UMPTs should be accompanied by measures that mitigate their potential side-effects and also that countries should consider using a wider set of policies on top of UMPTs so as to avoid overburdening the central bank.

These changes in the monetary policy stance (mostly from advanced economies in control of the leading currencies) have had and continue to have spillover effects on other countries (commonly to emerging market countries). ${ }^{69} \mathrm{In}$ this regard, an International Finance Discussion Papers (IFDP) Note published on the Fed's website in February 2016 provides a short but comprehensive analysis on the basic issues connected to the international spillovers of monetary policy. ${ }^{70}$ In this note the authors highlighted that the discussions on the topic are not new but started in the early interwar period and recovered relevance in the aftermath of the GFC due to the use of conventional and unconventional monetary policies by central banks in order to provoke monetary stimulus.

The authors of the IFDP Note recognized that international spillovers can be positive or negative, mainly subject to the strength of the channels of transmission. ${ }^{71}$ However, they acknowledged that beyond the cost/benefit analysis

69 It is not only the policy change but also the discontinuity of the policies that brings associated spillovers. To illustrate this point Lastra provides the example of QE in the US and the effects of the so-called 'tapering'. See Lastra (n 1 ) 39-40.

70 John Ammer and others, 'International Spillovers of Monetary Policy' (2016) IF D P Notes $<$ https://federalreserve.gov/econresdata/notes/ifdp-notes/2016/international-spilloversof-monetary-policy-20160208.html> accessed 21 October 2021.

71 On this point Janet Yellen, former chair of the Fed, recognises the international linkages of domestic monetary policy by stating that: monetary policy actions in one country spill over to other economies through three main channels: changes in exchange rates; changes in domestic demand, which alter the economy's imports; and changes in domestic financial conditions - such as interest rates and asset prices - that, through portfolio balance and other channels, affect financial conditions abroad.

Janet L Yellen, 'Speech' The Elusive 'Great' Recovery: Causes and Implications for Future Business Cycle Dynamics, Boston, 14 October 2016 <https://federalreserve.gov/ newsevents/speech/yellen20161014a.htm> accessed 21 October 2021. For further detail on the channels of transmission see chapter 6 of this book. 
of the impact of the spillovers, the key issue relates to the impact of monetary spillovers on the stability of the global economy. On this issue the authors pointed out that:

In response to common adverse shocks such as the GFC, the positive spillovers of easing actions by the Federal Reserve and other central banks proved stabilizing for the global economy. Conversely, some years afterwards, these positive spillovers from ongoing policy accommodation were not welcomed by emerging market economies (EMEs) whose cyclical positions had much improved. ${ }^{72}$

Consequently, the authors conclude on this issue that international monetary policy spillovers can have both stabilizing and destabilizing effects on the global economy depending on the business-cycle ${ }^{73}$ situation of states globally. ${ }^{74}$

It can be argued that the particular business-cycle of states also influences the course of monetary policy directions opted by central banks worldwide. For that reason, Benoit Cœuré, a member of the executive board of the Есв, considers that 'the global economy is currently characterised by an environment of diverging monetary policy cycles ${ }^{75}$ and as an illustration on the point

72 John Ammer and others ( $\mathrm{n} 7 \mathrm{O})$.

73 ibid. The Oxford Dictionary of Finance and Banking provides a definition of 'business cycle' that reads as follows: The process by which investment, output, and employment in an economy tend to move through a recurrent cycle of upturn, prosperity, downturn, and recession. The cycle does not describe a regular pattern in either length or amplitude. Cycles in the immediate postwar period were of historically low amplitude, while those of the late 1970's and 1980's had greater amplitude and involved much deeper recessions. The reasons for the business cycle remain little understood.

Law and Smullen (eds) (n 36 ).

74 Accordingly, Albagli and others remarked that: While increased financial integration has multiple benefits, it also presents important challenges. In particular, it raises the question of whether the cost of funds in non-core economies can remain independent from developments in major financial centers, possibly undermining the ability of central banks in setting appropriate monetary conditions given each country's macroeconomic stance.

Elias Albagli and others, 'Channels of US Monetary Policy Spillovers into International Bond Markets' <https://bis.org/events/ccaconf2017/ccaconf2017_12.pdf> accessed 3 December 2019.

75 Benoît Cœuré, 'Domestic and Cross-Border Spillovers of Unconventional Monetary Policies' (sNB-IMF Conference 'Monetary Policy Challenges in a Changing World', Zurich, May 2015) <https://ecb.europa.eu/press/key/date/2015/html/sp150513.en.html> accessed 21 October 2021. 
he presents the example of interest rate level disparities among the euro area and the United States of America. ${ }^{76}$ Similarly, a special report issued by The Economist in 2018 remarked that:

This divergence between America and the rest means divergent monetary policies, too. The Federal Reserve has raised interest rates eight times since December 2015. The European Central Bank (ЕСв) is still a long way from its first increase. In Japan rates are negative. China, the principal target of Mr Trump's trade war, relaxed monetary policy this week in response to a weakening economy. When interest rates rise in America but nowhere else, the dollar strengthens. That makes it harder for emerging markets to repay their dollar debts. A rising greenback has already helped propel Argentina and Turkey into trouble; this week Pakistan asked the IMF for a bail-out. ${ }^{77}$

Cœuré also remarks that this pattern of 'global monetary policy divergence' also brought with it the debate on the loss of monetary policy independence. On this point he argues that:

central banks in large advanced economies can free themselves from the global financial cycle and regain monetary independence, provided that they show clarity in purpose and resolve in implementation. ... For emerging markets and smaller advanced economies, there is also evidence that while the global financial cycle has indeed been a dominant factor for the last two decades, the arrangement of open macro policies such as the exchange rate regime and financial openness still have direct influence on sensitivity to the financial cycle. ${ }^{78}$

Accordingly, Lastra argues that 'the ability to have a truly independent monetary policy diminishes with the growth of cross-border capital flow' ${ }^{79}$ The matters of monetary policy independence and the global business-cycle are intrinsically related to the so called 'monetary trilemma' identified almost 60 years ago by the economists Mundell (1963) and Fleming (1962). ${ }^{80}$ This trilemma

76 ibid. While the Fed reacted to the GFC by implementing a series of interest rate cuts, the ЕСВ maintained the interest rate unchanged for much longer.

77 The Economist, The Next Recession (11 October 2018).

78 Benoît Cœuré (n 75$)$.

79 Lastra (n 1 ) 24-25.

8o Robert A Mundell, 'Capital Mobility and Stabilization Policy under Fixed and Flexible Exchange Rates' (1963) 29(4) The Canadian Journal of Economics and Political Science 
considers that there is a policy trade-off among three objectives that cannot be achieved at the same time so governments must give up one of them. The conflicting objectives are: a fixed exchange rate, free capital movements and an independent monetary policy. A recent and influential study on this policy trade-off made by Hélène Rey considers that it is not a trilemma, but a dilemma between free capital movements and the control of local financial conditions. ${ }^{81}$

Mark Carney, former governor of the Bank of England, has argued in 2019 that those players at the center of the IMs, like the Fed, need to incorporate spillovers and spill backs. He also considers that

central banks need to develop a better shared understanding of the scale of global risks and a recognition that concerted, cooperative action may sometimes be necessary ... That doesn't mean that monetary policy makers in advanced economies must internalise fully spillovers from their actions on emerging market economies, given their mandates are to achieve domestic objectives. They must, however, increasingly take account of effects that spill back on their economy as well as shifts in the global equilibrium interest rate that their actions can spur. ${ }^{82}$

While recognizing the value of the studies performed by economic literature on the trade-offs connected to the issues associated with the so-called monetary trilemma or dilemma, the trade-offs that I want to highlight and discuss throughout this book are related but different. The economist monetary trilemma debates the trade-off among three competing policy objectives at the same level of governance (monetary policy, exchange rate policy and capital movements). That level of governance is the domestic level or, in the case of

475; Marcus J Fleming, 'Domestic Financial Policies under Fixed and under Floating Exchange Rates' (1962) 9(3) Staff Papers International Monetary Fund, 369.

81 Rey argues that: For the past few decades, international macroeconomics has postulated the 'trilemma': with free capital mobility, independent monetary policies are feasible if and only if exchange rates are floating. The global financial cycle transforms the trilemma into a 'dilemma' or an 'irreconcilable duo': independent monetary policies are possible if and only if the capital account is managed.

Hélène Rey, 'Dilemma not Trilemma: The Global Financial Cycle and Monetary Policy Independence' (2013) Proceedings - Economic Policy Symposium - Jackson Hole, Federal Reserve of Kansas City Economic Symposium, 285-333.

82 Mark Carney, 'Speech' (The Growing Challenges for Monetary Policy in the current International Monetary and Financial System, London, 23 August 2019) $11<$ www.bis.org/ review/r19o827b.htm > accessed 21 October 2021. 
the euro zone, the regional level. However, this study is interested in the tradeoff among different levels of governance. Specifically, the trade-off among policies aimed at domestic and regional monetary stability and the stability of the overall IMS. This trade-off reached its peak during the GFC, triggered by the international spillovers of monetary policy. Consequently, I analyse in further detail this trade-off in the following chapters as it is a regulatory gap which I want to raise awareness to in legal doctrine.

\section{$4 \quad$ Conclusion}

This chapter claims that the term 'international monetary stability' encompasses the smooth functioning of the core elements of the IMS in an integrated global economy and the absence of cross-border negative spillovers generated by domestic monetary policies. Also, this chapter argues that there is a clear trade-off among the stability objectives at the different levels of governance of the international monetary order. It also contends that this trade-off benefits the stability of the domestic and regional orders over the stability of the whole international monetary order.

Accordingly, the Rapport Camdessus remarks that:

There is no unified global governance structure to help ensure that major economic and financial policy decisions made nationally, including exchange rate policies, are mutually consistent and contribute to global stability. In a world so deeply inter-connected, economic outcomes in each country depend significantly on developments and policy decisions made in others. In such a world, there is a strong case for rules and processes to be developed to help ensure that major economic and financial policy decisions made nationally are mutually consistent and contribute to global stability. ${ }^{83}$

Consistent with the observations made by the Rapport Camdessus in the aftermath of the GFC, the next chapter introduces the emerging doctrine of Common Concern of Humankind as a valid methodological approach to issues that require a collective action response from the international community, like the stability of the IMS.

83 Rapport Camdessus (n $\left.5^{8}\right) 4$. 